\title{
Hamilton Awakening
}

\author{
Michael G. Abraham, MD FAHA \\ Departments of Neurology and Radiology, \\ University of Kansas Medical Center, Kansas City, Kansas
}

What's that in the future? Someone call my name? Did someone call my name? Hello?

Out of the depths I hear I heard there's a stir, good sir good Samaritan.

Calling out to me calling out to us. Did they remember? Did they realize?

I tried I tried, while down there to finalize.

The plans the paragraphs, the pettiness of political puffed up partisan pompousness.

I ran, I supported, I saw the future. The possibility of a future a time a place where we are all kings and queens. I learned how to live, and not die, and my wings, they were energized.

Where did the pulse come, from where did the fire gets its spark?

Deep, deep, deep in the Caribbean, when I was dropped as a drop in the middle of the delving depths.

There was one, there was deux, trois, quatre, cinq, six, et sept?

I wrote, I wrote, I could not stop. The mind of the words, had to come out.

Words were said, words were sung, prose and poetry.

One last dance, one last waltz, as words I said, stung through walls.

People gathered around, people made their plans, it quickly got cold, my friend...his thoughts.

My numbers added up, but not enough to hide the hidden hatred of harlequins.

I rallied, I riled...I reminisced, ruminated, and remembered how I rose from the reckless bottoms.

I learned how to live, and not die, but death caught me.

Caught me when I tried to avoid delivering its message across the sea.

Did I know that the bullet would strike from the west.

Kissing me below the chest, sending me to my final rest?

Down, down, down to the Caribbean.

The echo in my heart, the beats were trembling down. 